\title{
THE IMPACT OF FLOOR CROSSING ON ELECTORAL POLITICS AND REPRESENTATIVE DEMOCRACY IN LESOTHO
}

\author{
Khabele Matlosa and Victor Shale
}

\author{
Dr Khabele Matlosa is Senior Advisor-Research at EISA \\ 14 Park Road Richmond Johannesburg \\ Tel: +27 11482 5495; Fax: +27 114826163 \\ e-mail: khabele@eisa.org.za
}

\begin{abstract}
Victor Shale is a Researcher at EISA and a Political Science doctoral candidate at the University of South Africa

e-mail: victor@eisa.org.za
\end{abstract}

\begin{abstract}
There is a firm consensus among both academics and policy analysts that political parties are the linchpin of representative democracy. However, parties require, among other things, internal cohesion, democratic and visionary leadership, intra-party democracy and constructive management of internal conflict as well as mutually beneficial inter-party relations if they are to add value to representative democracy. Without the above qualities political parties on their own, and through the legislature, may not play their role effectively. While floor crossing or political migration, in and of itself, is not necessarily undesirable in a democracy, if not well managed it accentuates the proliferation of parties, a trend that may have adverse effects on already fragmented party systems and fledgling representative democracies such as that prevailing in Lesotho. In the discussion that follows we examine the impact on Lesotho's representative parliamentary democracy of faction fighting and party schisms, which, in turn, lead to floor crossing.
\end{abstract}

\section{INTRODUCTION}

This paper discusses the impact of floor crossing on party systems and representative democracy in Lesotho. It focuses mainly on major floor crossing (sometimes termed 'political migration'* ) developments in 1997, 2001, and 2006, which have led to party breakaways and changes of government.

* For the sake of simplicity the expression floor crossing will be used throughout this paper 
Migration is often associated with human movement within or between countries. Within countries it involves the movement of people mainly from rural to urban areas, and between countries it involves the movement of people from less developed to relatively well-developed countries. At the heart of migration is the hope of improved socio-economic conditions and we deliberately invoke this notion to suggest that a similar mindset is at play in floor crossing or political migration in legislatures, namely, that a politician or politicians move from one party to another in the hope that the new party will offer better prospects for accessing state power. The primary thrust of this article is three-pronged, namely:

- Floor crossing in Lesotho, although permissible constitutionally, undermines the country's representative parliamentary democracy.

- Floor crossing is a clear manifestation of Lesotho's fragmented party system, which is not sufficiently robust for the institutionalisation of democracy; it therefore reinforces the fragility of the country's democracy, since the historic political transition of 1993.

- Given that floor crossing is a feature of the constituency-based electoral system Lesotho inherited from the British in 1966, with the reform of the electoral model towards more proportionality and the adoption of the mixed member proportional (MMP) system it was assumed that this problem would be redressed, but recent developments suggest that this has not been the case; in fact, the country's current political crisis is marked by even more fragmentation of the party system, which directly and indirectly destabilises Parliament and other spheres of governance.

Following these introductory remarks we will provide a brief political context for our discussion of floor crossing and its impact on electoral politics and representative democracy. We then move onto the links between floor crossing and the electoral system.

This will be followed by a discussion of the links between floor crossing and the party system and an exploration of the possible impact of floor crossing on Parliament and representative democracy. Before concluding the paper we outline immediate challenges posed by the 2006 floor crossing and the emergence of the new political party. The conclusion wraps up the debate and sums up our main observations.

\section{THE POLITICAL SETTING}

Lesotho has a parliamentary democracy with a dual governance system - the government is headed by the prime minister, the state by the king. Lesotho, 
therefore, operates the Westminster political system whereby the prime minister is appointed by the king on the advice of the State Council from a party with the majority of seats in Parliament. The king remains head of state by virtue of his traditional status, which is hereditary. It is an unusual system, blending modern democracy with traditional governance, a rare hybrid in Southern Africa.

Government in Lesotho, like that in other countries, operates through three main organs, namely, the executive, the judiciary, and the legislature, with two others, the bureaucracy and the security establishment, playing supplementary and subsidiary roles. Typically, the executive tends to dominate the other organs of state. For the purposes of this paper the focus will be on the legislature. The country has a bicameral Parliament (ie, an Upper House or Senate, and a Lower House or National Assembly - NA). The 33-member Senate is constituted through appointments made by the king on the advice of the prime minister. The majority of the appointees are principal chiefs from the country's 22 wards. The other 11 senators are appointed from among distinguished members of the community. The 120-member NA, the elected house, is the main law-making organ of the state. The Upper House holds the Lower House to account. A Bill can only become law after it has been passed by both the upper and lower houses.

Although Lesotho is a parliamentary democracy one prominent feature of the country's political history has been its political instability since its independence in 1966. While it is not the task of the present paper to investigate the factors behind the entrenched culture of instability in Lesotho we note that in many ways this instability has tended to undermine the institutionalisation of the country's democracy. Our interest is to find out to what extent the fragmentation and faction fighting within political parties, especially those represented in Parliament, fans and fuels this instability (Matlosa \& Sello 2005; Kadima, Matlosa \& Shale 2006).

As will become clear in the discussion below, the politics of floor crossing interfaces dynamically with electoral and party systems. This is so because an electoral system facilitates the formation of parliaments and party systems determine the way in which political parties operate and interrelate both within and outside Parliament.

\section{THE ELECTORAL SYSTEM AND FLOOR CROSSING}

Upon its political independence in 1966 Lesotho adopted the Westminster system of governance, including its plurality-majority or first-past-the-post (FPTP) electoral system - the system that makes it possible for members of Parliament to move (or migrate) from one party to another (cross the floor). This movement of MPs, although allowed by the Constitution, permissible on the basis of the electoral 
system, and governed by parliamentary rules (standing orders), frequently has unintended consequences such as fragmenting the party system, destabilising Parliament, undermining the legitimacy and accountability of MPs, and, above all, devaluing representative democracy.

The major floor-crossing episode to shake Lesotho's political system took place in 1997, in the first election to follow the historic transition from military dictatorship to multiparty democracy in 1993 and the election of that year, the outcome of which was a landslide victory for the BCP, as illustrated in Table 1.

Table 1

General Election Results 1993

\begin{tabular}{|l|c|c|c|}
\hline Party & No of votes & \% of votes & No of seats \\
\hline BCP & 398355 & 74.7 & 65 \\
\hline BNP & 120686 & 22.6 & 0 \\
\hline MFP & 7650 & 1.4 & 0 \\
\hline Other & 6287 & 1.2 & 0 \\
\hline Total & $\mathbf{5 3 2} \mathbf{9 7 8}$ & $\mathbf{1 0 0 ^ { * }}$ & $\mathbf{6 5}$ \\
\hline
\end{tabular}

Source: Matlosa, 2002

* Figure rounded up

The $\mathrm{BCP}$ won all 65 constituencies, hence all the seats in the NA, leaving all the other parties in the cold despite the fact that they had together garnered about 25 per cent of the total votes.

While this development may have been good news for the $\mathrm{BCP}$, which then formed a new government in a democratic dispensation, political success came with costs. Not only did the new government confront a plethora of challenges, including conflicts with the security forces and the monarchy, but, importantly for the discussion in this paper, the party faced an internal menace: faction fighting and power struggles. Thus, the political honeymoon for the newly elected BCP proved brutally ephemeral. Disagreements began to surface over the leadership of the party and the sharing of the spoils emanating from control of the state. Tensions mounted and the one-party Parliament began to develop internal cracks as opposition emerged within the monolithic ruling party.

This internal feuding was not based upon ideological or policy differences but on a leadership tussle involving members of the party hierarchy. The political tug-of-war between the factions within the $\mathrm{BCP}$ resulted in a rupture which 
followed a special conference organised by the party's leader, Prime Minister Ntsu Mokhehle, which convened on 7 June 1997 and was attended by about 1000 delegates. According to Mokhehle the main purpose of the conference was to deliberate on the internal problems of the $\mathrm{BCP}$, which had, for more than a year, been involved in legal battles which caused delays in preparations for the 1998 election (Hansard 9 June 1997). At the conference a decision was taken to establish a new party. A breakaway group was formed, known as the Lesotho Congress for Democracy (LCD).

Led by the prime minister the newly-established party enjoyed the support of a majority of MPs (40), subsequently displacing the BCP (which was left with $25 \mathrm{MPs}$ ). To the chagrin of the BCP the LCD became the ruling party simply on the basis of its numerical strength in Parliament and the BCP, despite the numerical strength conferred on it by the 1993 election, was declared the official opposition, a designation the party denounced publicly.

The LCD became the de facto authority, replacing the BCP government and constitutionally acceptable despite allegations of a coup d'état and despite that fact that it had not been put into power through a popular vote. Announcing the formation of the LCD at a press conference at the Parliament buildings on 9 June 1997 the prime minister declared that 'since in this move we enjoy the support of a majority of MPs, there will be no change of government. Those who prefer to remain with the $\mathrm{BCP}$, we wish them luck in their new role as official opposition in parliament. I request them to nominate the leader of opposition and submit the name to the Speaker of Parliament, so that government is able to accord him/her the requisite privileges' (Hansard 9 June 1997).

Immediately after the press conference the Speaker of the NA exhorted the $\mathrm{BCP}$ to nominate and submit the name of the leader of the opposition. A profound sense of political bitterness ensued as the BCP felt cheated and unfairly elbowed out of power. This bitterness, and the tension among political parties, set the stage for the 1998 election, which was to be followed by deep-seated and violent conflict. The LCD won the election and its popular choice seemed to legitimise the 1997 split. The outcome of the 1998 election is illustrated in Table 2.

It was, therefore, no surprise that the $\mathrm{BCP}$ and other opposition parties, notably the Basotho National Party (BNP) and the Marematlou Freedom Party (MFP) rejected the election outcome and resorted to political violence which nearly plunged the country into a civil war. Although the LCD won only 61 per cent of the vote it secured 79 of the 80 seats.

As was the case in 1993 the 1998 election effectively produced a one-party Parliament and again, as happened after the 1993 election, Parliament was poised to experience internal problems, especially relating to internal cohesion, faction fighting and floor crossing. It therefore came as no surprise when there was a 
Table 2

General Election Results 1998

\begin{tabular}{|l|c|c|c|}
\hline Party & No of votes & \% of votes & No of seats \\
\hline LCD & 355049 & 60.7 & 79 \\
\hline BNP & 143073 & 24.5 & 1 \\
\hline BCP & 61793 & 10.5 & 0 \\
\hline MFP & 7460 & 1.3 & 0 \\
\hline Other & 16244 & 2.9 & $\mathbf{8 0}$ \\
\hline Total & $\mathbf{5 8 3 6 1 9}$ & $\mathbf{1 0 0}$ & 0 \\
\hline
\end{tabular}

Source: Matlosa 2002

* Figure rounded up

split in the LCD hardly five years after its formation, with its deputy leader leaving the party to form the Lesotho Peoples' Congress (LPC), which was registered with the Law Office on 8 October 2001. The existence of the party was formally announced in the NA on 12 October. After being advised by a letter from the party's general secretary, Shakhane Robong Mokhehle, a younger brother of Ntsu Mokhehle, that some members of the party were MPs, the Speaker requested those involved to cross the floor. A total of $27 \mathrm{MPs}$ did so, joining the LPC under the leadership of Kelebone Maope, former deputy prime minister and minister of justice, human rights and constitutional affairs. The LPC then assumed the role of opposition. After the floor crossing, the Speaker made the following appeal:

Honourable Members, today we have reached a sad day for our democracy, although I am comforted by a sense of joy on your faces. As many of you know, floor crossing in parliament often destabilises parliament as it is accompanied by a problem of accepting these new changes as well as ensuring cooperation among factions. Be that as it may, I truly and humbly appeal to everyone of you that during these trying times, you be vigilant. Everyone of you should remember that you are here in this House because of votes by the electorate; you were chosen among many contestants. The electorate chose you because they had trust in you given your understanding, compassion and appreciation of their problems. But above all you had shown trust in the eyes of the electorate. 
A year later (2002) Lesotho reformed its electoral system, abandoning FPTP and adopting MMP. It must be emphasised that when the system changed it was assumed that the country's election-related conflicts would subside and the problem of floor crossing be minimised. This was not entirely the case, as will become evident. Within the framework of the new system the size of the NA was increased from 80 to 120 seats, 80 filled by means of FPTP, the rest through the party-list proportional representation (PR) system. The only MPs who may cross the floor and retain their seats are the 80 elected by constituencies, the 40 elected by PR lose their seats if they do so. The original intention of the designers of Lesotho's electoral system was that all elections subsequent to that of 2002 would be organised on the basis of a 1:1 ratio of PR:FPTP seats. At the time of writing this had not yet been effected - the ruling party appears to have developed cold feet.

\section{THE PARTY SYSTEM AND FLOOR CROSSING}

Conventionally, there are four types of party systems. The one-party system obtains where one party (the ruling party) dominates the political scene and no other party has any prospect of dislodging it from power. The two-party system (duopoly) prevails in a setting where there are two dominant parties each with an equal chance of constituting a government. A dominant-party system is one in which even if there is a multiplicity of parties only one exercises such profound hegemony that it tends to reproduce itself as the ruling party over a long period in successive elections in which the opposition parties are fragmented, disjointed and enfeebled. A multiparty system presupposes a political setting in which there are many parties, each with a roughly equal chance of controlling state power. Lesotho does not fit neatly into any of these scenarios, due, in large measure, to the fact that the country's party system is generally marked by fragmentation and both the ruling and the opposition parties tend to experience fragmentation brought about by internal faction fighting and splits.

Not only do parties in Lesotho lack a culture of cooperation for mutual gain, internally they tend to engage in unending faction fighting, which undermines their organisational cohesion and institutional effectiveness. This problem is even more acute among parties represented in Parliament. Parties in Lesotho generally lack intra-party democracy and thus internal conflict must either be resolved through the courts or, if that route fails or the aggrieved factions do not consider it viable, a party split is inevitable. Not only does this trend destabilise parties, it tends to destabilise Parliament and generates uncertainty in the process of nurturing and consolidating the country's newfound democracy. In the decade since Lesotho re-introduced multiparty democracy none of its major political parties has been spared faction fighting and splits. 
Since the BCP split in 1997, leading to the formation of the LCD, and the further split of the LCD, leading to the formation of the LPC in 2001, another major faction has caused political tremors within the ruling party. Following its overwhelming electoral victory in 2002 (see Table 3), the ruling LCD has not avoided contracting Lesotho's age-old political cancer of fragmentation.

Table 3

General Election Results 2002

\begin{tabular}{|l|c|c|c|}
\hline Main Parties & No of votes & \% of votes & No of seats \\
\hline Lesotho Congress for Democracy & 304316 & 54.8 & 79 \\
\hline Basotho National Party & 124234 & 22.4 & 3 \\
\hline Basutoland African Congress & 16095 & 2.9 & 3 \\
\hline Basutoland Congress Party & 14584 & 2.7 & 5 \\
\hline Lesotho Peoples' Congress & 32046 & 5.8 & 1 \\
\hline National Independence Party & 30346 & 5.5 & 1 \\
\hline Lesotho Workers' Party & 7788 & 1.4 & 1 \\
\hline Marematlou Freedom Party & 6890 & 1.2 & 1 \\
\hline Popular Front for Democracy & 6330 & 1.1 & $\mathbf{1 2 0}$ \\
\hline National Progressive Party & 3985 & 0.7 & $\mathbf{1 0 0 ^ { * }}$ \\
\hline Total & $\mathbf{5 4 6 6 1 4}$ & & 21 \\
\hline
\end{tabular}

Source: IEC, Results of the National Assembly Elections 2002

* Figure rounded up

As was the case with the emergence of the LCD in 1997 and the LPC in 2001, this latest development occurred about a year in advance of a general election scheduled for mid-2007. Just days after Lesotho's celebration of its 40 years of independence on 4 October 2006 the Minister of Communications, Science andTechnology, Motsoahae Thomas Thabane, announced his resignation as a Cabinet Minister and member of the ruling LCD amid rumours that he might form a new party.

Indeed, the Speaker of Parliament received a letter dated 10 October 2006 advising her that 'a new political party has been registered under the following name: All Basotho Convention [ABC]. Some of the founding members of the said 
party are Members of the National Assembly.' Consequently, during the 13th meeting of the Sixth Parliament, on 13 October, 17 members of the LCD crossed the floor to join the ABC. They were joined by L Tsehlana, MP for Mokhotlong Constituency number 79, who had been expelled from the LCD in February 2004 but had not lost his seat. This brought the total number of ABC MPs to 18 .

The leader of the $\mathrm{ABC}$ gave a number of reasons for his move, including a failure to implement agreed policies and corruption in the public sector. However, there is no gainsaying that the overriding factor was the intensity of the power struggle, particularly in relation to the successor to the current party leader, Prime Minister Pakalitha Mosisili. The LCD, which had won 79 seats (all constituencybased) in the 2002 election, was reduced to 61 and a new opposition party with $18 \mathrm{MPs}$, second only to the BNP (with 21), emerged. The LCD now had 61 seats, the combined opposition 59 .

Table 4

Party Representation in the National Assembly after the Floor Crossings

\begin{tabular}{|l|c|c|c|}
\hline Parties & $\begin{array}{c}\text { No of seats after } \\
\text { the 2002 election }\end{array}$ & $\begin{array}{c}\text { No of seats } \\
\text { after floor crossing }\end{array}$ & Gain/Loss \\
\hline Lesotho Congress for Democracy & 79 & 61 & -17 \\
\hline Basotho National Party & 21 & 21 & 0 \\
\hline All Basotho Convention & - & 18 & +18 \\
\hline Basutoland African Congress & 3 & 3 & 0 \\
\hline Basutoland Congress Party & 3 & 5 & 0 \\
\hline Lesotho Peoples' Congress & 5 & 5 & 0 \\
\hline National Independence Party & 5 & 1 & 0 \\
\hline Lesotho Workers' Party & 1 & 1 & 0 \\
\hline Marematlou Freedom Party & 1 & 1 & 0 \\
\hline Popular Front for Democracy & 1 & 1 & 0 \\
\hline National Progressive Party & 1 & 3 & 0 \\
\hline
\end{tabular}

Source: The Authors

The question is whether or not this development strengthened or further fragmented Lesotho's party system; enhanced or inhibited the effectiveness of the legislature; and ultimately strengthened or weakened the country's representative democracy. It is to these fairly complex issues that the next section turns. 


\section{IMPACT OF FLOOR CROSSING ON REPRESENTATIVE DEMOCRACY}

It should be emphasised that Lesotho's politics tends to be characterised by the zero-sum nature of engagement of politicians across and within parties. Part of the explanation for this is the country's limited resources. Small, landlocked, and impoverished, Lesotho has always been mired in conflict-ridden politics, in part, because the political elite perceives politics (through parties and the legislature) as a licence to access state resources.

Given the bleak prospects for gaining wealth in the private sector the state becomes a major avenue for accumulation and this explains why the contest among the elite for state power becomes so fierce and has generated protracted violent conflicts in the past. In the light of this, what exactly are the prospects of building and sustaining representative democracy in a poor country like Lesotho, which has no sound economic base? This answer to this question is beyond the scope of this paper, but it should be a consideration in any discussion of the dilemmas of representative democracy in the country.

However, explaining the problem in structuralist (socio-economic) terms alone may not tell the full story. It is important also to emphasise that in addition to the structural determinants leadership plays a crucial role in political parties, the legislature, and democracy. Democracy requires democrats as its agents. If leaders are democrats they are bound to embrace a democratic ethos. If they are not they are not likely to run their parties democratically. If parties are not run democratically they are bound to experience endless infighting and conflict, which may not be managed constructively, resulting in fragmentation and splits. As the old saying goes, democracy cannot exist without democrats.

Lesotho's fragmented party system and factional politics undermine the parties and adversely affect the legislature. Put somewhat differently, the state of political parties determines the success or otherwise of a Parliament comprising those parties. From the tradition of the one-party system during the heyday of BNP rule (especially between 1970 and 1986) through the era of a no-party system under the military regime (1986-1993) Lesotho's political system has been marked by a fragmented party system characterised by a proliferation of weak parties.

This, in part, is a consequence of the overwhelming majority of the ruling party in Parliament, which has bred factionalism - a phenomenon that would be less prevalent if there were strong and effective opposition parties. Needless to say, the absence of such parties has not been the result of ideological differences but of the struggle for power.

This is illustrated by Mahao (1999), who shows that some members of the BCP made numerous attempts to oust the party's leader. In this regard it is worth 
noting that all the major party splits and floor crossing in Lesotho have taken place just as a general election is on the horizon, a trend that suggests that power struggle is a major factor. The combined effect of power struggles and the lack of intra-party democracy within political parties further compound their existential crisis and help us to understand and explain the splits and floor crossing.

Furthermore, floor crossing in Lesotho, as elsewhere, takes place without the consent of the rank and file membership, hence some observers perceive it as unfair and a betrayal of the voters. Broadly, the impact of floor crossing on Lesotho's representative democracy can be identified at five levels. First, it changes the political complexion of the National Assembly and alters the outcome of general election results. This means that results can easily be altered by elite pacts and the realignment of power in the National Assembly, as happened after the 2002 election when the LCD, which had originally won 79 parliamentary seats, ended up with only 61 after the formation of the ABC.

Second, the proliferation of small, weak parties created by floor crossing further compounds the problem of a fragmented party system in an emerging democracy such as that of Lesotho. While a multiparty system is good for democracy it has its own dangers, including a proliferation of small parties with strong leaders. Third, when MPs cross the floor they are not compelled to consult their constituencies in advance, neither are they compelled to seek a new mandate, a situation which undermines the accountability of MPs to the electorate.

It is interesting to note that after the formation of the $\mathrm{ABC}$ the leaders of the new party organised a public rally at Ha Abia (Lithoteng Constituency No 34) on Sunday 22 October 2006 to introduce the party to the constituency the party leader had represented as an LCD MP since the 2002 election. On the same day the LCD leadership, including the secretary general, Mpho Malie, and the deputy leader, Lesao Lehohla, organised another public rally in the same constituency with a view to explaining to voters that their MP had left them in the lurch (Mololi 26 October 2006; Public Eye 27 October-2 November 2006).

Fourth, it has also been observed that one of the weaknesses of political parties in Lesotho (and other emerging democracies in the region) is their lack of mutually reinforcing inter-party relations by way of cooperation and alliances where their ideological and programmatic positions coincide and open avenues for inter-party unity. It was only in 2006 that three parties - the BAC, the BCP and the LPC - formed an alliance known as the Alliance for Congress Parties (ACP), which aimed to contest elections under one banner in 2007.

It is possible that the MMP electoral model is resulting in a proliferation of small parties. While one feature of the model is that it encourages the formation of new parties it also encourages party coalitions, power-sharing and national unity governments. 
Finally, if not well managed, floor crossing may undermine representative democracy in that if the electorate keeps electing MPs who, after a while, undermine their choice by switching political allegiance, voters may feel the MPs only represent themselves. This situation may generate a legitimacy crisis for the MPs in the eyes of the electorate, which may, in turn, result in declining public trust in both MPs and parties. Available data from the Afrobarometer surveys suggest that public trust in political parties is declining in all Southern African Development Community (SADC) countries and it is opposition parties which suffer most.

\section{IMMEDIATE CHALLENGES POSED BY THE 2006 FLOOR CROSSING}

The political temperature in Lesotho seemed to be on the rise ahead of the 2007 election, possibly due to the anxiety caused by the emergence of a new political player. As illustrated above this development undoubtedly transformed the complexion of party representation in Parliament overnight. But other developments were at play too, two of which are worth exploring.

Firstly, the country was about to undergo the African Peer Review Mechanism (APRM) by means of which Lesotho's governance architecture would be assessed in terms of robustness and any possible deficits that need redressing. There is no doubt that one of the major deficits of the country's governance is the fragmentation of its party system, which is likely to feature in the APRM report as one of the weaknesses of Lesotho's new democracy.

The signing of the Memorandum of Understanding (MoU) between Lesotho and the APRM Secretariat, which took place on Wednesday 15 November 2006, launched the Lesotho APRM process, led by Dr Chris Stals (a member of the APRM Panel of Eminent Persons). It is a sensitive process that requires political stability as it unfolds. If instability sets in the whole process is likely to be adversely affected. There is no gainsaying that intra-party instability may have the ripple effect of destabilising inter-party relations and this, in turn, if it is not wellmanaged, has the potential to trigger political instability at a national level. This instability is more likely in the context of preparations for a general election.

The emergence of a new political party meant that the political environment in the run-up to the February 2007 general election was increasingly electric. The response of the main political players, especially the ruling party, to the floorcrossing development and the subsequent emergence of the $\mathrm{ABC}$ had the potential either to trigger instability or to ensure a stable environment ahead of the election. It was therefore essential that political violence be avoided because it is axiomatic that the political environment within which an election takes place is crucial in determining the credibility of the process and the legitimacy of its outcome. 
On Friday 24 November 2006 His Majesty King Letsie III dissolved Parliament. In terms of the Constitution and the electoral law, once this has been done an election must be held within 90 days. At its meeting on 29 November 2006 the State Council decided that a snap general election would be held on 17 February 2007. Fortunately the opposition parties retracted earlier threats to boycott the poll, committing themselves to participate despite the challenges posed by inadequate preparation time, which would affect voter registration, the selection of candidates, the nomination process, the training of party agents, resource mobilisation, party campaigns, and so on.

\section{CONCLUSION}

If political parties are to play their rightful role in the nurturing and consolidation of democracy they must exhibit a considerable degree of internal cohesion and institutional effectiveness. We have argued in this paper that parties in Lesotho lack these qualities and that consequently the country's party system is generally fragmented, with both ruling and opposition parties experiencing internal discord and disharmony, characterised by conflict and faction fighting which frequently lead to schisms.

When this happens it is not only the parties that suffer but other institutions as well. These include the legislature - the key political institution for representative democracy wherein parties play an active role in the law-making process. A legislature is only as good as its constituent parts (ie, the MPs). If the constituent parts are weak and fragmented, the legislature is bound to be adversely affected. Faction fighting within parties triggers breakaways and schisms and a proliferation of parties through floor crossing.

Lesotho's new democratic dispensation has seen major party schisms: in 1997 (the emergence of the LCD from the BCP), 2001 (the emergence of the LPC from the LCD), and 2006 (the emergence of the ABC from the LCD).

These floor-crossing developments share two features: all involved leadership squabbles and some degree of intra-party conflict and all took place shortly before a national election.

We conclude that while the country's constitutional framework and electoral system allow for floor crossing it tends to further fragment Lesotho's party system, destabilise its parliamentary system, and thereby undermine its newfound representative democracy. While Prime Minister Mosisili bemoaned the schisms within his ruling LCD (in 2001 and in 2006) he was confident that the new parties did not pose an electoral threat to his party, arguing that the LCD would still win the general election in 2007 - as, indeed, it did - just as the party won the 2002 general election after the 2001 split and floor crossing (Mololi 26 October 2006). 
Although the LCD won the 2007 election there is no doubt that the emergence of the $A B C$ prior to the election had a significant influence on the nature of the configuration of power and on the electoral contest and a major influence on the post-election political trajectory in Lesotho.

\section{RECOMMENDATIONS}

The following four recommendations flow from the discussion above. They relate directly to the three main issues raised in the paper: floor crossing and representative democracy; floor crossing and the party system; and floor crossing and the electoral system.

- In many respects floor crossing (political migration) may run counter to the deepening of representative democracy in Lesotho, in particular by destabilising Parliament. It is likely that one of the factors behind declining public trust in the legislature has to do with floor crossing. The Parliamentary Reform Committee set up to transform the National Assembly of Lesotho should, among other things, look into how best to contain the adverse effects of floor crossing in order to minimise the loss of public trust in this democratic institution.

- The building and sustainability of a strong and durable party system depends, in part, upon parties' resources both during and between elections. Political parties require a whole range of resources - human, technological, infrastructural and financial - if they are to become effective agents of representative democracy, but it is financial resources they need most. In this regard, it would be worthwhile for Lesotho to consider introducing public funding of parties represented in Parliament to be used for their institutional development instead of merely for their campaigns (which is the case at present). It is quite possible that lack of resources and the lure of resources elsewhere are among the contributory factors to the intra-party factionalism which leads to splits and floor crossing.

- One of the major triggers of intra-party faction fighting, schisms, and ultimately floor crossing is an absence of intra-party democracy and mechanisms for constructive management of conflicts. Political parties in Lesotho need to make a deliberate effort to institutionalise these elements.

- Floor crossing subverts electoral systems and the mandates given to MPs by the electorate, thus running counter to the accountability of MPs to their 
constituencies. In order to institutionalise such accountability as an important ingredient of representative democracy Lesotho should consider a constitutional provision enabling the electorate to recall constituencybased MPs when voters feel the MP no longer lives up to the expectations of the constituency.

\section{- REFERENCES}

Hansard. Third Meeting-Second Session of the Fourth Parliament, Monday 9 June 1997.

. Third Meeting-Second Session of the Fifth Parliament, Friday 12 October 2001. Kadima, D, K Matlosa \& V Shale. 2006. Enhancing the Effectiveness of Political Parties in the SADC Region through Public Outreach Programmes: Focus on Botswana, Lesotho, Namibia and Zambia. Johannesburg: EISA Research Report No 29.

Mahao, N. 1999. 'Solving the Structural and Political Crises in Lesotho'. In K Lambrechts (ed). Crisis in Lesotho: The Challenge of Managing Conflict in Southern Africa. Johannesburg: Foundation for Global Dialogue (mimeo).

Matlosa, K. 2002 'Lesotho'. In T Lodge, D Kadima \& D Pottie (eds). Compendium of Elections in Southern Africa. Johannesburg: EISA.

— _ \& C Sello. 2005. Parties and Political Development in Lesotho. Johannesburg: EISA Research Report No 23.

Mololi 6(41), 26 October 2006.

Public Eye10(43), 27 October-2 November 2006.

Southall, R \& T Petlane. 1995. Democratisation and Demilitarisation in Lesotho: The General Election of 1993 and its Aftermath. Pretoria: Africa Institute of South Africa. 